\title{
EFFICACY OF INVASIVE GREEN MANURES AND MYCORRHIZA ON GROWTH AND YIELD OF DIFFERENT LEGUMES CROPS AND STUDY THEIR ANTIMICROBIAL PROPERTIES
}

\author{
Geeta Shrestha Vaidya* and Nabin Bhattarai** \\ * Shigan International College(SICOST), ** Megha National College, Kathmandu, Nepal.
}

\begin{abstract}
Application of the invasive green manure (locally available Lantana camara, Eupatorium adenophorum) is an essential means to maintain soil fertility, soil structure and stimulate biological activities extensively. In this present study field trial of Lentil and Rajma were conducted in Kosebali Divison of Rampur, Chitwan district. Mycorrhiza was isolated from agricultural soil by sugar decantation method and mass production with the help of onion plant. Leaves of Lantana camara and Eupatorium adenophorum were collected and shed dried and grinded on powdered form. The treatments with green manures and mycorrhizae showed higher yield than the control in case of Lentil field trial. In case of Rajma field trial, length of stems and dry seed formation was higher in Eupatorium adenophorum and followed by Lantana camara, chemical fertilizer, control and mycorrhiza. Mycorrhizal spores were found higher in Lantana camara followed by Eupatorium adenophorum, mycorrhizal, chemical fertilizer and control. The number of mycorrhizal spores was found higher in case of Lantana camara followed by Eupatorium adenophorum, mycorrhiza, compost, chemical fertilizer and control. The percentage of seedless and low seeded pods were found higher on control followed by compost, chemical fertilizer, Lantana camara, Eupatorium adenophorum and mycorrhiza.
\end{abstract}

Keywords: Invasive green manure; Mycorrhizae; Chemical fertilizer; Antimicrobial properties; Chitwan district.

\section{INTRODUCTION}

Green manure is a type of cover crop grown primarily to add nutrients and organic matter to the soil. Green manures are rich in mineral, organic matters and bioactive compounds which help for better growth of plants and control of plant diseases. Green manure means planting a crop that is meant to be incorporated into the soil to increase it's fertility level, reduce erosion, improve the physical condition of the soil, and reduce nutrient loss from leaching and helps keep the rich topsoil from being washed away. It is used to protect the soil from erosion, weed control, disease control especially soil born diseases and nematodes. It is a cheap alternative to artificial fertilizers and can be used to complement animal manures, Eupatorium adenophorum and Lantana camara are exotic and invasive plants to Nepal and highly compete and disturb the growth of other plants.

In Nepal farming is mixed, subsistence and heavily dependent on forest resources, such as leaf litter, green manure, poles, fuel wood, fodder and non-timber forest products (Mahat 1987; Kadariya 1992). The quantity of chemical fertilizer used per hectare in Nepal is very low as compared to other countries. However farmers who have been using chemical fertilizer in Kathmandu valley and some of the Terai districts have started to experience its adverse effects on soil quality.
Soil in Nepal is deficient in N,P,K due to shortage of organic matter in the soil (Shrestha Vaidya et al. 2008). Therefore incorporation of organic matter is necessary for improvement and fertility of soil. Organic matter can replace the use of chemical fertilizers as much as possible. Therefore mycorrhizal fungi are essential for the establishment of tree seedlings and for their good growth (Shrestha Vaidya et al. 2002, 2005).

So, addition of organic matter can have a beneficial effect on the growth of indigenous AM fungi in nutrient limited soil (Caravaca et al. 2002; Gaur \& Adholeya 2002). Organic amendments enhance spore production (Johnson \& Mc Graw 1988, Douds et al. 1997, Shrestha Vaidya et al 2008). Organic matter addition to the soil at eroded sites could thus be appropriate to enhance the beneficial effect of AM fungi for soil stabilization and plant establishment and it also protects environment over the long term and reduces cost of production. Giovanetti and Avio (1985) suggested that this beneficial effect might be related to increased pore volume in soil which has a beneficial effect on AM colonization, the mycorrhizal growth response and AM spore numbers. Furthermore, Ryan et al. (1994) attributed increased AM fungal biomass to the beneficial effects of organic matter on soil structure, water status and on synergistic microbial activities in the soil.

Author for Correspondence: Geeta Shrestha Vaidya, Shigan International College (SICOST), E-mail: geetashrestha1@ hotmail.com. 


\section{MATERIALS AND METHODS}

Laboratory work of this research work were conducted in the Nepal Academy of Science and Technology lab and field trial was conducted in Kosebali Division, Rampur, Chitwan district where Lentil and Rajma were cultivated. Endomycorrhizal spores were extracted from agricultural soil using wet sieving and sucrose centrifugation (McKenney \& Lindsey 1987) and mass production of mycorrhizae for field trial were done with the help of onion plant.

For preparation of green manures, leaves of Lantana camara and Eupatorium adenophorum were collected from chobhar kirtipur and shed dried and grinded on powdered form. The field trials were designed on

\section{Lentil: Field Trial}

Table 1: Lentil Field trial treatments showing average length, pod and seedless formation with different treatments.

\begin{tabular}{lcllll}
\hline $\begin{array}{l}\text { Treat } \\
\text { ments }\end{array}$ & $\begin{array}{l}\text { Total no. of } \\
\text { uprooted } \\
\text { plants }\end{array}$ & $\begin{array}{l}\text { Average } \\
\text { length of } 40 \\
\text { plants }(\mathbf{c m})\end{array}$ & $\begin{array}{l}\text { Average } \\
\text { no. of pods } \\
\text { formation }\end{array}$ & $\begin{array}{l}\text { Average no. of } \\
\text { pods formation } \\
\text { with seed }\end{array}$ & $\begin{array}{l}\text { Average no. } \\
\text { of seedless } \\
\text { pods formation }\end{array}$ \\
\hline T1 & 40 & 23.97 & 29.95 & 22.22 & 4.72 \\
T2 & 40 & 25.57 & 45.45 & 38.55 & 6.90 \\
T3 & 40 & 27.70 & 56.90 & 48.67 & 8.22 \\
T4 & 40 & 23.99 & 50.82 & 43.90 & 7.70 \\
T5 & 40 & 21.97 & 18.80 & 14.19 & 4.61 \\
T6 & 40 & 22.10 & 27.20 & 22.77 & 4.42 \\
\hline
\end{tabular}

\section{Lentil: Field Trial}

Table 2 : Lentil Field trial treatments showing seeded and seedless pod formation weight of seed, waterholding capacity and average mycorrhzal spores.

\begin{tabular}{lcccccc}
\hline $\begin{array}{l}\text { Treat } \\
\text { ments }\end{array}$ & $\begin{array}{l}\text { \%of seedless } \\
\text { pods form }\end{array}$ & $\begin{array}{l}\text { \% of seeded } \\
\text { pods form }\end{array}$ & $\begin{array}{l}\text { Wt. of 100 } \\
\text { seeds gm }\end{array}$ & $\begin{array}{l}\text { \% of water } \\
\text { holding } \\
\text { capacity }\end{array}$ & $\begin{array}{l}\text { Bulk density } \\
\text { gcm }^{-3}\end{array}$ & $\begin{array}{l}\text { Average } \\
\text { mycorrhizal spores } \\
\text { on 25 gm soil }\end{array}$ \\
\hline T1 & 15.77 & 84.23 & 2.31 & 30.67 & 1.48 & 21.33 \\
T2 & 15.18 & 84.82 & 2.62 & 33.43 & 1.45 & 61.33 \\
T3 & 14.45 & 85.55 & 2.81 & 34.92 & 1.56 & 50.00 \\
T4 & 15.15 & 84.85 & 2.68 & 33.62 & 1.46 & 45.00 \\
T5 & 24.51 & 75.49 & 2.18 & 30.87 & 1.57 & 11.33 \\
T6 & 16.26 & 83.73 & 2.31 & 31.92 & 1.53 & 42.66 \\
\hline
\end{tabular}

From field trial it was found that lentil plots treated with Eupatorium adenophorum showed higheraverage growth of stem and pods formation followed by mycorrhizal, Lantana camara, chemical fertilizer, compost and control. Higher the yield of dry seed was found with chemical fertilizer treatment followed by Lantana camara, Eupatorium adenophorum, mycorrhizal, compost and control. Higher water holding capacity was found in soil having Eupatorium adenophorum followed by Mycorrhiza, Lantana camara, control and chemical randomized block design. The collected data were presented in following table 1. $\mathbf{T}_{1}^{-}$Fertilizer, $\mathbf{T}_{2}^{-}$ Lantana camara, $\mathbf{T}_{3}-$ Eupatorium adenophorum, $\mathbf{T}_{4}{ }^{-}$ mycorrhizal, $\mathbf{T}_{\mathbf{5}}-$ Control. All treatments have four replicates.

In the case of field trial of lentil, $1.7 \mathrm{~kg} /$ plot $(2.833$ $\mathrm{t} / \mathrm{ha}$ ) Mycorrhizal inoculums, each green manures 2.275 $\mathrm{kg} /$ plot (3.45 t/ha), compost $6 \mathrm{~kg} /$ plot (6 t/ha) and ratio of NPK 20:40:20 kg/h were applied. In case of Rajma, green manures $1.5 \mathrm{~kg} /$ plot (7.5 t/ha), mycorrhizae $800 \mathrm{~g}$ /plot (4.00 t/ha) and ratio of NPK 120:40:40 kg/h applied

\section{RESULTS}

It has been observed that the treatments with green manures and mycorrhizae showed higher yield than the control. 
Table 3:

\begin{tabular}{lcccccc}
\hline $\begin{array}{l}\text { Treat } \\
\text { ments }\end{array}$ & $\begin{array}{l}\text { No. of } \\
\text { maintained plants }\end{array}$ & $\begin{array}{l}\text { No. of survival } \\
\text { of plants }\end{array}$ & $\begin{array}{l}\text { Average length } \\
\text { of plants }(\mathrm{cm})\end{array}$ & $\begin{array}{l}\text { Total no. of } \\
\text { seeds sown }\end{array}$ & $\begin{array}{l}\text { Germination } \\
\text { of plants }\end{array}$ & $\begin{array}{l}\% \text { of } \\
\text { germination }\end{array}$ \\
\hline T1 & 200 & 190 & 21.53 & 400 & 307 & 76.75 \\
T2 & 200 & 197 & 21.50 & 400 & 286 & 70.15 \\
T3 & 200 & 196 & 23.76 & 400 & 292 & 73.00 \\
T4 & 200 & 176 & 16.98 & 400 & 297 & 74.25 \\
T5 & 200 & 191 & 19.28 & 400 & 287 & 70.17 \\
\hline
\end{tabular}

\section{Rajma: Field Trial}

Table 4 :

\begin{tabular}{lllllll}
\hline $\begin{array}{l}\text { Treat } \\
\text { ments }\end{array}$ & $\begin{array}{l}\text { Weight of dry } \\
\text { seed formation } \\
\text { of all plots of } \\
\text { each treatment } \mathrm{g} .\end{array}$ & $\begin{array}{l}\text { Total weight of } \\
\text { dry seed formation of } \\
\text { all plots of each } \\
\text { treatment g. }\end{array}$ & $\begin{array}{l}\text { Water } \\
\text { holding } \\
\text { capacity } \\
(\%)\end{array}$ & $\begin{array}{l}\text { Bulk } \\
\text { density } \\
\text { gmcm }^{-3}\end{array}$ & $\begin{array}{l}\text { Average } \\
\text { mycorrhizal } \\
\text { spores on } \\
25 \text { g. soil }\end{array}$ & $\begin{array}{l}\text { Wt. of } \\
100 \\
\text { seeds g. }\end{array}$ \\
\hline T1 & 145.00 & 0.14 & 32.08 & 1.39 & 19.66 & 64.00 \\
T2 & 432.00 & 0.43 & 33.04 & 1.37 & 65.66 & 53.00 \\
T3 & 530.10 & 0.53 & 32.99 & 1.39 & 53.30 & 48.00 \\
T4 & 52.20 & 0.05 & 33.81 & 1.46 & 45.00 & 49.00 \\
T5 & 132.50 & 0.13 & 32.51 & 1.38 & 5.66 & 48.00 \\
\hline
\end{tabular}

Average length of stems and dry seed formation was higher in treatment with Eupatorium adenophorum, followed by Lantana camara, chemical fertilizer, control and mycorrhiza. Eupatorium adenophorum and Lantana camara treated treatments showed green, vigorous growth and least death of seedlings. The percentage of germination was higher in chemical fertilizer followed by mycorrhiza, Eupatorium adenophorum, control and Lantana camara (Table 3). The bulk density and water holding capacity was found higher in mycorrhiza followed by Eupatorium adenophorum, chemical fertilizer, control and Lantana camara. Mycorrhizal spores were found higher in Lantana camara, Eupatorium adenophorum, mycorrhizal, chemical fertilizer and control (Table 4).

\section{DISCUSSION}

Organic amendments enhanced spore production of AM mycorrhiza (Johnson and Mc Graw 1988; Douds et al. 1997; Shrestha Vaidya et al. 2008) which is similar to this results. The organic materials also improve the microbial activities of the soil, biological $\mathrm{N}$ fixation, organic matter decomposition, mineralization, nitrification and antagonism to soil borne pathogens (Alam and Khan 2001). Improved nutrient and water uptake by the plants can be expected in response to better AM growth and the positive effect on the growth of AM fungi is in good agreement with results obtained by other authors, who also found that organic matter addition increased AM fungal hyphal growth (Labidi et al. 2007; Joner and Jakobsen,1995) and AM spore formation (Douds et al. 1997; Muthukumar and Udaiyan, 2000; Gryndler et al. 2003; Harinikumar and Bagyaraj 1989). In addition, St John et al. (1983) and Friberg (2001) found that AM fungal hyphae grew best in soils with a high amount of organic matter which is shown in our results also. Ravnskov et al. (1999) had shown that effects of organic compounds on growth of AM fungi in soil vary according to chemical composition of the substrate which was similar to present study. The present result has shown that Lantana and Eupatorium are better than other treatments. Same type of study was reported by Nziguheba et al. (2000). The application of organic materials reduces the soil bulk density and hence increases total porosity, which has a positive effect on plant growth. In a compact soil, mycorrhizal symbiosis can enhance the uptake of nutrients by plant roots since mycelium of hyphae penetrates small pores more easily than roots (Nadian et al. 1996). Saikia et.al.2011 had shown that conservation of all available bio-mass provides high amount of organic matter in tea sections which adds good amount of nutrient to the soil. The present study provides the first information on a stimulating effect of organic material addition on extraradical growth of AM fungi in Nepal. These results show that organic matter addition can improve plant survival. 


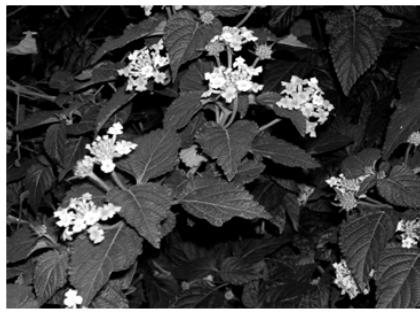

Lantana camara (Linn.)

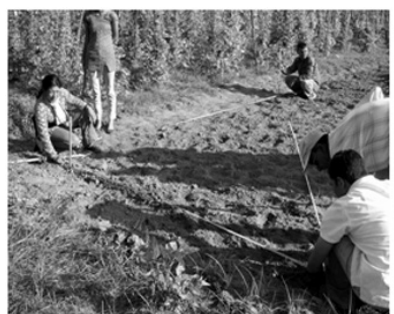

Rajma Seeds

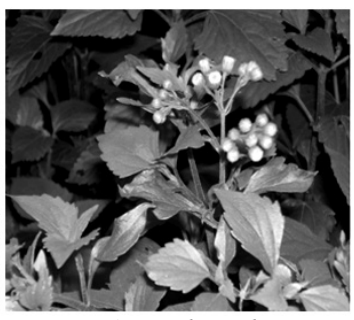

Eupatorium adenophorum (Sprang.)

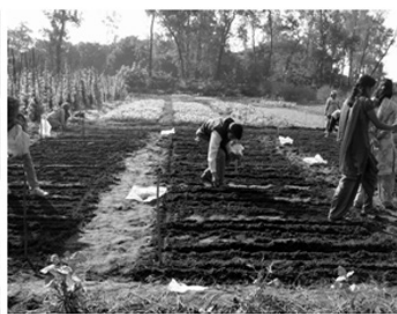

Planting Rajma Seeds

\section{CONCLUSION}

Green manures and mycorrhiza were effective for the growth and yield of Lentil and red kidney bean (Rajma), and can be used as biofertilizer which is environmentally friendly, cost effective and save the national money for purchasing the chemical fertilizer. The application of organic materials reduces the soil bulk density and hence increases total porosity, which has a positive effect on plant growth.

\section{ACKNOWLEDGEMENTS}

We would like to thank Dr. Renuka Shrestha (Chief of the Kosebali Division) for providing the field for field trial and cooperation on field trial. Our thanks to Nepal Academy of Science and Technology (NAST) for permission to do this work.

\section{REFERENCES}

Alam, S. M. and Khan, M. A. 2001. Organic and effective microorganisms technology, http://www.pakistaneconomist.com/issue2001/ issue 26/i\&e6.htm.

Caravaca, F. J. M. Barea and Roldán, A. 2002. Synergistic influence of an arbuscular mycorrhizal fungus and organic amendment on Pistacia lentiscus L. seedlings afforested in a degraded semi-arid soil. Soil Biology and Biochemistry. 34:1139-1145.

Douds, D. D., Galvez, L., Franke-Snyder, M., Reider, G. and Drinkwater, L. E. 1997. Effect of compost addition and crop rotation point upon VAM fungi. Agriculture, Ecosystems and Environment. 65:257-266.

Friberg, S. 2001. Distribution and diversity of arbuscular mycorrhizal fungi in traditional agriculture on Niger inland delta, Mali, West Africa. CBN: Skriftserie. 3: 53-80.

Gaur, A. and Adholeya, A. 2002. Arbuscular- Mycorrhizal inoculation of five tropical fodder crops and inoculum production in marginal soil amended with organic matter. Biology and Fertility of Soils. 35:214218.

Giovanetti, M. and Avio, L. 1985. VAM infection and reproduction as influenced by different organic and inorganic substances. In Proceedings of the 6th NorthAmerican Conference on Mycorrhizae (R.Molina. Ed.) Forest Research Laboratory. Bend, Oregon

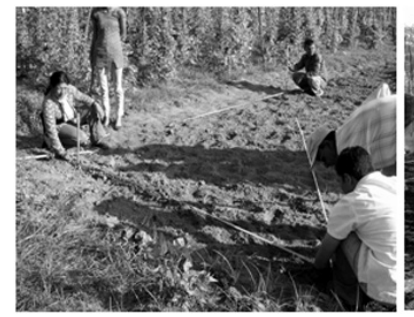

Random method Field Trial in Kosebali Rampur

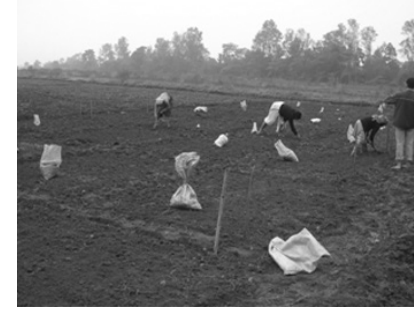

Making the plot \& mixing the fertilizers for Lentil field trial

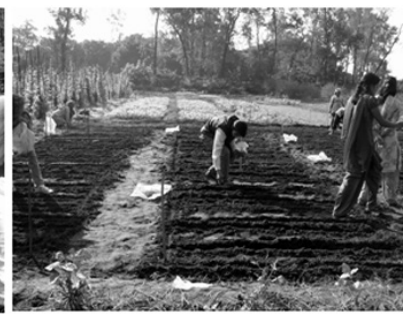

Seeding in the Field Trial

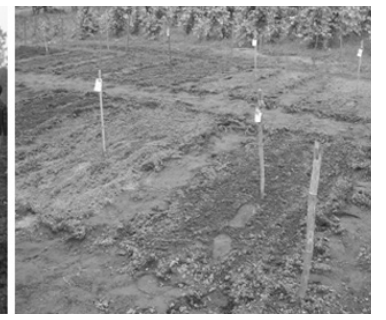

After seeding Lentil in field trial

Gryndler, M., Vosatka., M., Hrselova, H., Chvatalova, I. and Jansa, J. 2003. Interaction between arbuscular mycorrhizal fungi and cellulose in growth substrate. Applied Soil Ecology. 19: $279-288$.

Harinikumar, K. M. and Bagyaraj, D. J. 1989. Effect of intercropping and organic soil amendments on native VAM. A Mahadevan A, N Raman and K, Natarajan (eds). In Mycorrhizas for green AsiaCentre for Advanced Studies in Botany, Madras, India, 207-208.

Johnson, N. C. and McGraw A. C. 1988. Vesicular-arbuscular mycorrhizae in taconite tailings II. Effects of reclamation practices. Agriculture Ecosystems and Environment. 21:143-152.

Johnson, N. C. and McGraw, A. C. 1988. Vesicular-arbuscular mycorrhizae in taconite tailings II. Effects of Reclamation practices. Agriculture Ecosystems and Environment. 21: 143-152.

Joner, E. J. and Jakobsen, I. 1995. Growth and extracellular phosphatase activity of arbuscular mycorrhizal hyphae as influenced by soil organic matter. Soil Biol Biochem. 27: 1153-1159.

Kadaria, B. K. 1992. The development of sustainable livestock production systems in the Midhills of Nepal, based upon agroforestry concepts LAC, Seminar Paper No. 19.

Labidi, S., Nasr, H., Zouagui, M. and Wallander, H. 2007. Effects of compost addition on extra-radical growth of arbuscular mycorrhizal fungi in Acacia tortilis sp. Raddiana savanna in a pre-Saharan area. Applied Soil Ecology. 35: 182- 194.

Mahat, T. B. S. 1987. Forestry-Farming Linkages in the Mountains. ICIMOD Occasional Paper 7, Kathmandu, Nepal.

McGaw, L. J. and Eloff, J. N. 2005. Screening of 16 poisonous plants for antibacterial, anthelminitic and cytotoxic activity in vitro. South Afr J Bot. 71: 302-306.

McKenney, M. C., and Lindsey, D. L. 1987. Improved method for quantifying endomycorrhizal fungi spores from soil. Mycologia. 79:779-782.

Muthukumar, T. and Udaiyan, K. 2000. Influence of organic manure on arbuscular mycorrhizal fungi associated with Vigna unguiculata (L.) Walp. in relation to tissue nutrients and soluble carbohydrate in roots under field conditions. Biology and Fertility of Soil. 31: 114-120

Nadian, H., Smith, S. E., Alston, A. M. and Murray, R. S. 1996. The effect of soil compaction on growth and $\mathrm{P}$ uptake by Trifolium subterraneum: interaction with mycorrhizal colonization. Plant and Soil. 182 : 39-49.

Nziguheba, G., Merckx, R., Palm, C. A. and Rao, M. R. 2000. Organic residues affect phosphorus availability and maize yields in a Nitisol of 
Western Kenya. Biology and Fertility of Soils. 32:328-339.

Ravnskov, S., Larsen, J. , Olsson, P. A. and Jakobsen, I. 1999. Effect of various organic compounds on growth and phosphorous uptake of an arbuscular mycorrhizal fungus. New Phytol. 141: 517-524.

Ryan, M. H., Chilvers, G. A. and Dumaresq, D. C. 1994. Colonisation of wheat by VA-mycorrhizal fungi was found to be higher on a farm managed in an organic manner than on a conventional neighbour. Plant and Soil. 160: 33-40.

Saikia, D.N., Sarma Dutta, J.P.K. and Baruaha, D.K. 2011. Sustainable productivity of tea through conservation of bio-mass, addition of biofertilizers and reduction of inorganic. Two and a Bud. 58: 109-117,

Sharma, G. P., Raghubanshi, A.S. and Singh, J. S. 2005. Lantana invasion: An overview. Weed Biol Manage. 5: 157-165.

Sharma, O. P., Makkar, H. P., Dawra, R.K. and Negi, S. S. 1981. A review of toxicology of Lantana camara (Linn) in animals. Clin Toxicol. 18: 1077-1094. [PubMed]
Shrestha Vaidya, G., Shrestha, K., Khadge, B.R., Johnson, N.C. and Wallander, H. 2008. Organic matter stimulates arbuscular mycorrhizal fungi in Bauhinia purpurea and Leucaena diversifolia plantations on eroded slopes in Nepal . Restoration Ecology. 16: 79-87.

Shrestha Vaidya, G. and Piya, S. 2002. Study of Antagonistic Action of Two ectomycorrhizal fungi isolated from Pine forest of Dadeldhura. Proc. International Seminar on Mountain, March 6-8: 571 - 577.

Shrestha Vaidya, G., Shrestha, K. and Wallander, H. 2005. Antagonistic Study of Ectomycorrhizal Fungi Isolated from Baluwa Forest (Central Nepal) against with pathogenic Fungi and Bacteria. Scientific World. 3: $49-52$.

St. John, T. V., Coleman, D. C. and Reid, C. P. P. 1983. Association of vesiculararbuscular mycorrhizal hyphae with soil organic particles. Ecology. 64: 957-959. 